\title{
Application of ELISA recomWell HEV IgG (Human) for Detection of Virus-Specific Antibodies in Sera of Slaughtered Rabbits
}

\author{
Ewelina Bigoraj ${ }^{1}$ - Artur Rzeżutka ${ }^{1}$ \\ Received: 25 July 2018 / Accepted: 12 September 2018 / Published online: 19 September 2018 \\ (C) The Author(s) 2018
}

\begin{abstract}
$\mathrm{HEV}$ infections in animals are mainly diagnosed based on the presence of anti-HEV antibodies in sera using enzyme-linked immunosorbent assays (ELISA). In fact, commercial HEV ELISA kits are only available for selected animal species excluding rabbits. The demonstration of cross-reactivity of rabbit anti-HEV antibodies with human HEV strains makes possible diagnostic use of (human) ELISA kits for detection of specific anti-HEV antibodies in rabbit sera. The aim of the study was the application of ELISA recom Well HEV IgG (human) for identification of HEV seropositive rabbits at the time of slaughter. Native recombinant protein A was used as broadly reactive conjugate characterized by cross-species reactivity with IgG antibodies of human and other animal species. Several dilutions of protein A were employed and subsequently tested against the panel of control sera (positive, negative, and borderline) to determine its optimal concentration. Statistical analysis of OD values and their corresponding antibody titers obtained for each group of tested sera and protein A showed the most consistent performances at 1:40,000 dilution when compared to anti-human IgG (control) conjugate. Finally, the correct performance of the optimized test was verified using rabbit serum samples containing (or not) specific anti-HEV antibodies. As demonstrated here, HEV IgG (human) ELISA employing ORF2 antigens of human gt1 and gt3 HEV strains after modification and subsequent optimization can be used for the detection of anti-HEV antibodies in rabbit sera.
\end{abstract}

Keywords Hepatitis E virus · Rabbit · ELISA · Detection

\section{Introduction}

Hepatitis E virus (HEV) infects humans and many species of farm and wildlife animals (Johne et al. 2014). HEV infections in animals have an asymptomatic course with no significant impact on animal health. Such infections in humans and in particular in immunocompromised persons and pregnant women can cause serious health consequences (Goumba et al. 2010; Nelson et al. 2018). Although rabbit HEV strains belong to the rabbit HEV genotype cluster, they are genetically and antigenically closely related to pig and wild boar HEV strains which are known to infect humans (Yugo and Meng 2013; Johne et al. 2014; Doceul et al. 2016). The virus has been found in farmed, wild, and pet rabbits (Caruso et al.

Artur Rzeżutka

arzez@piwet.pulawy.pl

1 Department of Food and Environmental Virology, National Veterinary Research Institute, Al. Partyzantów 57, 24-100 Puławy, Poland
2015). HEV infections in rabbits are asymptomatic and therefore tissues of asymptomatically infected animals can easily enter the food chain. Currently, there is a lack of data on cases of $\mathrm{HEV}$ infection in humans related to the consumption of rabbit meat but a risk of zoonotic infection with rabbit $\mathrm{HEV}$ potentially exists.

Rabbit meat is very popular among consumers in Europe, and its consumption in some countries reaches nearly $6 \mathrm{~kg}$ per capita. Due to a significant $(21 \%)$ content of protein with good digestibility, mineral and vitamin B group content, and low levels of fat and cholesterol, it is recommended especially for allergic persons, pregnant women, and children (Szkucik and Pyz-Łukasik 2009; Dalle Zotte and Szendro 2011). In 2014, world production of rabbit meat amounted to 1.6 million tons and $25 \%$ of rabbit meat was produced in the EU, in countries such as France, Italy, and Spain (Dorning and Harris 2017), which also have the highest rate of rabbit meat consumption (FAO 2014). Poland supplies $10 \%$ of the world's production of rabbit meat while itself having a low consumption rate (Anonymous 2014). Similarly, to meat of other food animals intended for human consumption, rabbit meat should be free from any microbiological hazards. Different types of bacterial 
pathogens are nevertheless sporadically detected in raw rabbit meat (Khalafalla 1993; Pyz-Łukasik and Szkucik 2005).

Diagnosis of HEV infections in rabbits is based on molecular detection of the viral genetic material or detection of specific anti-HEV antibodies in the blood of tested animals (Burt et al. 2016; Di Bartolo et al. 2016). The use of molecular methods is not always possible as virus presence in animal blood is associated with viremia, which is transient and disappears when seroneutralising antibodies appear (Geng et al. 2011). Nevertheless, these methods are irreplaceable in determination of virus genotypes or identification of the sources of infection. In epidemiological studies on the prevalence of HEV infections in animals, mainly enzyme-linked immunosorbent assays (ELISA) are used. However, HEV ELISAs are only commercially available for selected animal species such as pigs, wild boars, and ruminants, but not for rabbits (Eiden et al. 2011; Costanzo et al. 2015). Demonstration of crossreactivity of rabbit anti-HEV antibodies with human HEV strains (Izopet et al. 2012) makes possible diagnostic use of human ELISA kits for detection of specific anti-HEV antibodies in rabbits. The aim of the study was an adaptation of the ELISA recomWell HEV IgG kit (human) for identification of HEV seropositive rabbits at the time of slaughter.

\section{Materials and Methods}

\section{ELISA}

For the detection of the presence of anti-HEV antibodies in rabbit sera, a recomWell HEV IgG ELISA kit (Mikrogen Diagnostik) was used. This assay utilized a recombinant O2C fragment within HEV-ORF2 genotypes 1 and 3 (gt1 and gt3) as virus antigens.

\section{Antibody-Binding Protein A (Conjugate) and Preparation of Control Rabbit Sera}

A native recombinant protein A (Protein A-Peroxidase, Sigma-Aldrich) was used as a conjugate for the detection of rabbit anti-HEV antibodies using recomWell HEV IgG. This protein is characterized by cross-species reactivity with IgG antibodies of human, pig, rodents (rat and mouse), ruminants (cow, goat, and sheep), and companion animals (dog, cat, and rabbit). A panel of 28 positive and negative rabbit serum samples containing (or not) specific anti-HEV antibodies was prepared to verify the correct performance of the optimized test. Sera samples obtained from virus positive animals with (presence of HEV RNA in the liver) were considered "conditionally" positive sera, while other sera samples were labeled "conditionally" negative until their status was confirmed by in-house modified ELISA. The presence or absence of asymptomatic HEV infections in rabbits of which sera were included in the panel of control negative and positive serum samples was checked by the detection of viral RNA in a pair of samples consisting of liver and serum taken from the same animal. Blood and liver samples were collected from each animal at slaughter. To obtain sera, after coagulation, blood was centrifuged at $1000 \times g$ for $10 \mathrm{~min}$ at $4{ }^{\circ} \mathrm{C}$ and subsequently frozen at $-20{ }^{\circ} \mathrm{C}$ until use. Liver samples $(2 \mathrm{~g})$ were homogenized on ice with the addition of $1 \mathrm{ml}$ PBS and then centrifuged at 2$8{ }^{\circ} \mathrm{C}$ for $5 \mathrm{~min}$ at $14000 \times \mathrm{g}$. Isolation of viral RNA from liver homogenate and serum was performed using a QIAamp Viral RNA Mini Kit (Qiagen) according to the manufacturer's instructions. Detection of HEV RNA was carried out with a single-step real-time RT-PCR using an UltraSense One-Step Quantitative RT-PCR kit (Invitrogen) with primers and probe designed by Jothikumar et al. (2006). To control inhibition of the real-time RT-PCR, an IAC was included in each PCR reaction mix (Maunula et al. 2013). Additionally, to the IAC, the appropriate positive (HEV RNA standard) and negative (all reagents with distilled water instead of the template) controls were set up during molecular analyses (Maunula et al. 2013).

\section{Adaptation and Optimization of ELISA}

The recomWell HEV IgG assay was subjected to a modification in which the control conjugate (IgG anti-human antibodies) supplied with the assay was replaced with protein A (Protein A-Peroxidase, Sigma-Aldrich). This protein is reactive with human $\operatorname{IgG}$ and with antibodies of several animal species including rabbits. Dilutions of 1:20,000, 1:40,000, $1: 60,000$, and 1:80,000 of new conjugate in the sample dilution buffer were prepared.

In order to determine optimal concentration of protein $\mathrm{A}$, each its dilution was tested 10 times against the panel of control sera (positive, negative, and borderline) included in the kit. In parallel, each control serum was also tested using a conjugate supplied with the kit. The analysis was carried out according to the manufacturer's instructions. The cut-off value was the arithmetic mean of the optical density (OD) values obtained for two replicates of doubtful serum sample. The quotient of serum OD and the cut-off value for doubtful serum sample gave the antibody titer, which was expressed in units (U) per ml. The serum was considered positive when its cutoff value exceeded the borderline seropositivity of $24 \mathrm{U} / \mathrm{ml}$. When the value ranged from 20 to $24 \mathrm{U} / \mathrm{ml}$, the serum was considered doubtful. A value below $20 \mathrm{U} / \mathrm{ml}$ indicated a negative result. The correct performance of the modified assay was verified by testing of positive and negative panel of rabbit sera with the use of the optimal dilution of protein A as the conjugate. 


\section{Statistical Analysis}

A two-way analysis of variance (ANOVA) with interactions was used to assess significant differences between OD obtained for each group of tested control serum samples (positive, negative, and borderline sera) and control anti-human $\operatorname{IgG}$ conjugate including serial dilutions $(1: 20,000,1: 40,000$, $1: 60,000$, and $1: 80,000)$ of protein $\mathrm{A}-\mathrm{a}$ tested conjugate. Furthermore, differences between the OD values and the antibody titers $(\mathrm{U} / \mathrm{ml})$ obtained for each dilution of protein $\mathrm{A}$ in comparison to the control conjugate within each group of sera were analyzed using a one-way analysis of variance.

All calculations were performed with a Statgraphics Centurion v. XV (Statpoint Technologies, Warrenton, USA).

\section{Results}

The OD values obtained for each group of tested sera (positive, negative, and borderline) with protein A dilutions and control conjugate (IgG anti-human antibodies) differ significantly $(P<0.001)$ (Table 1$)$. The one-way analysis of variance performed on the basis of OD values for positive sera indicated the presence of statistically significant differences $(P<0.001)$ between control conjugate and protein A dilutions. Only the OD values obtained for positive sera when tested with protein $\mathrm{A}$ at 1:40,000 dilution did not differ significantly from the OD values of the control conjugate. It is noteworthy that solely OD values obtained at 1:20,000 dilution of the tested conjugate differed significantly from the control (Fig. 1a). In the case of negative sera, the values were not significantly different $(P=0.604)$. A significant difference $(P<0.001)$ between the tested dilutions of protein A and the control conjugate was shown for borderline sera. In fact, the OD values gained for tested sera samples using both 1:40,000 and 1:60,000 dilutions of the conjugate did not differ significantly compared to the control, although they differed significantly from each other (Fig. 1b). Analyzing the antibodies titers that define the tested serum as positive, negative, or borderline, there were not significant differences present $(P=0.008)$ between the group of positive sera tested with protein A (1:40,000 dilution) and the control conjugate. Similarly, the titer of negative sera obtained for the conjugate did not differ either at 1:40,000 or 1:60,000 dilution from the sera titers obtained with the control conjugate.

The correct performance of the optimized ELISA for the detection of anti-HEV IgG antibodies in rabbits was evaluated using a panel of rabbit sera samples. All "conditionally" positive sera originated from virus-positive animals as confirmed by molecular testing showed the level of anti-HEV IgG in a range from 56.7 to $183.7 \mathrm{U} / \mathrm{ml}$ (Table 2). In the case of sera that were considered "conditionally" negative based on molecular testing, ELISA also confirmed their seronegative status.

\section{Discussion}

ELISA-based assays are commonly used as screening tests in diagnostics of human and animal viral infectious diseases (Khudyakov and Kamili 2011; Abravanel et al. 2013). However, they are not always available for a wide variety of viruses infecting different animal species. Nowadays, dedicated ELISA assays are available for detection of HEV antibodies in human and pig serum. Although HEV has several genotypes, it has only one serotype. Therefore, expressed antigens from one virus genotype can theoretically react with antibodies directed against all four virus genotypes (Zhou et al. 2004; Zhao and Wang 2016; Wang et al. 2017). Additionally, it has previously been shown that different mammalian HEV genotypes have cross-immunoreactive epitopes (Zhao and Wang 2016). Taking this into account and considering the facts that rabbit HEV strains are closely related to genotype $3 \mathrm{HEV}$ strains and recombinant capsid protein of rabbit HEV crossreacted with antibodies raised against avian, rat, swine, and human HEV (Cossaboom et al. 2012), an attempt was
Table 1 Results of determination of the optimal concentration of protein A in ELISA

\begin{tabular}{|c|c|c|c|c|c|c|c|c|c|c|}
\hline \multirow[t]{3}{*}{ Control sera } & \multicolumn{2}{|c|}{$\begin{array}{l}\text { OD for control } \\
\text { conjugate }\end{array}$} & \multicolumn{8}{|c|}{$\mathrm{OD}$ for protein $\mathrm{A}$} \\
\hline & \multirow[t]{2}{*}{ Mean } & \multirow[t]{2}{*}{ SD } & \multicolumn{2}{|c|}{$1: 20,000$} & \multicolumn{2}{|c|}{$1: 40,000$} & \multicolumn{2}{|c|}{$1: 60,000$} & \multicolumn{2}{|c|}{$1: 80,000$} \\
\hline & & & Mean & $\mathrm{SD}$ & Mean & $\mathrm{SD}$ & Mean & $\mathrm{SD}$ & Mean & $\mathrm{SD}$ \\
\hline Positive & $1.215^{*}$ & 0.097 & $1.981 *$ & 0.254 & 1.508 & 0.296 & $0.899 *$ & 0.181 & $0.671 *$ & 0.187 \\
\hline Negative & 0.061 & 0.003 & 0.059 & 0.013 & 0.058 & 0.011 & 0.058 & 0.008 & 0.053 & 0.004 \\
\hline Borderline 1 & $0.346^{*}$ & 0.030 & $0.544 *$ & 0.089 & 0.410 & 0.091 & 0.275 & 0.058 & $0.219 *$ & 0.048 \\
\hline Borderline 2 & $0.360 *$ & 0.023 & $0.557 *$ & 0.128 & 0.406 & 0.136 & 0.256 & 0.042 & 0.217 & 0.040 \\
\hline
\end{tabular}

$\mathrm{SD}$, standard deviation obtained for 10 replicates

*Denotes a statistically significant difference compared to control conjugate $(P<0.001)$ 


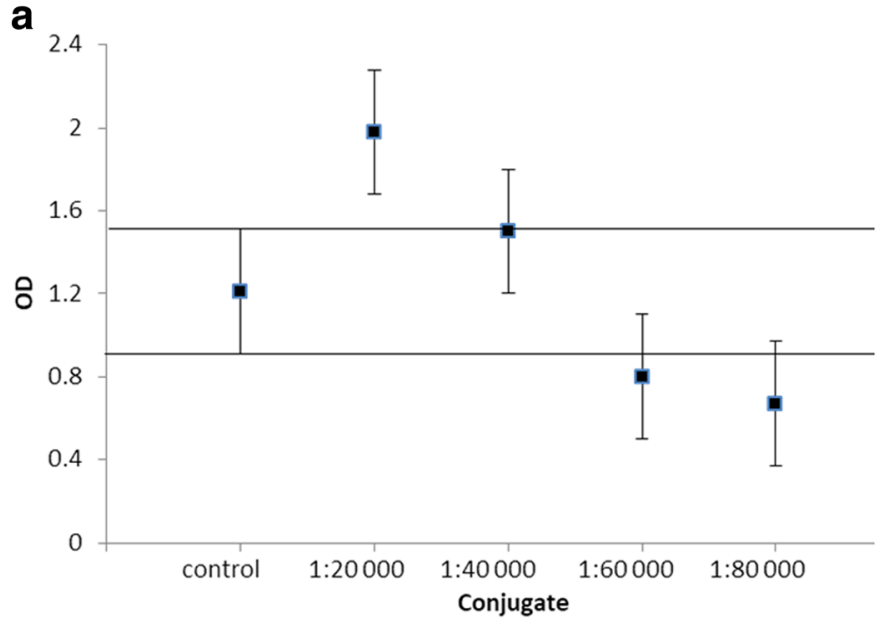

Fig. 1 OD values of positive (a) and borderline (b) sera obtained when analyzed with tested dilutions of the conjugate. Values outside the confidence interval indicated conjugate dilutions which differ significantly

undertaken to apply a commercially available ELISA containing antigens derived from human gt1 and $3 \mathrm{HEV}$ strains to the detection of anti-HEV antibodies in rabbit sera.

The HEV genome contains three open reading frames (ORFs) that encode structural proteins (ORF2) capable of inducing an immunological response and non-structural proteins (ORF1 and ORF3) essential for virus replication in cells (Emerson and Purcell 2003; Johne et al. 2014). Currently, different synthetic peptides and recombinant antigens of ORF 2 and 3 of genotypes 1,2, and 3 are used in serological diagnostics of human and animal HEV infections (Osterman

Table 2 Results of molecular and serological tests of rabbit liver and sera samples

\begin{tabular}{|c|c|c|c|c|}
\hline \multirow[t]{2}{*}{ No. of sample } & \multicolumn{2}{|c|}{ Real-time RT-PCR } & \multicolumn{2}{|l|}{ ELISA } \\
\hline & $\operatorname{Serum}(\mathrm{Cq})$ & Liver $(\mathrm{Cq})$ & OD & $\mathrm{U} / \mathrm{ml}^{*}$ \\
\hline 1 & - & 24.16 & 2.73 & 125.37 \\
\hline 2 & - & 27.67 & 4.00 & 183.70 \\
\hline 3 & - & 35.49 & 4.00 & 183.70 \\
\hline 4 & - & 32.26 & 3.34 & 153.48 \\
\hline 5 & - & 27.00 & 3.14 & 144.34 \\
\hline 6 & - & 40.01 & 3.37 & 154.99 \\
\hline 7 & - & 28.65 & 3.33 & 152.84 \\
\hline 8 & - & 32.77 & 1.67 & 76.74 \\
\hline 9 & - & 28.60 & 1.95 & 89.37 \\
\hline 10 & - & 28.82 & 1.77 & 81.47 \\
\hline 11 & - & 28.22 & 2.47 & 113.43 \\
\hline 12 & - & 24.93 & 1.23 & 56.67 \\
\hline 13 & - & 31.57 & 2.20 & 101.22 \\
\hline 14 & 43.91 & 27.51 & 1.39 & 63.97 \\
\hline $15-28$ & - & - & $<0.22$ & $<10.15$ \\
\hline
\end{tabular}

*Cut-off value 0.435

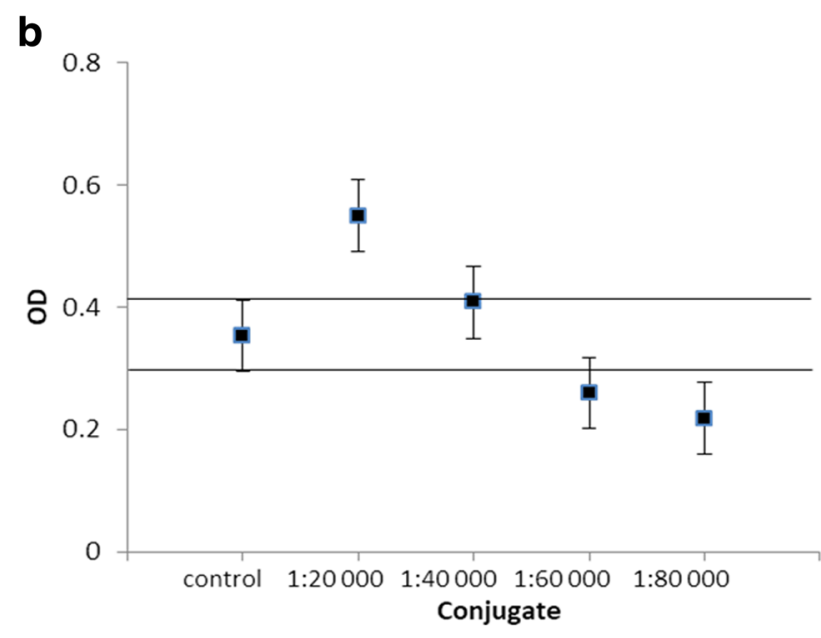

from the mean. The horizontal lines shows the ranges of confidence intervals (lower and upper limit) for the average OD value

et al. 2012; Riddell et al. 2000; Pezzoni et al. 2014; Wang et al. 2017). This could, to some extent, be explained by the fact that major antigenic epitopes of HEV are located more in the ORF2 (Wang et al. 2001) and ORF3 (Zhao et al. 2009) regions than in the ORF1 coding region (Osterman et al. 2012). Further studies characterizing the immunogenic properties of the ORF2- and ORF3-based recombinant virus proteins showed that ORF2 polyprotein, and especially its Cterminus part ( $\mathrm{O} 2 \mathrm{C}$ or $\mathrm{p} 166$ protein), is characterized by the highest immunogenicity among all tested virus antigens so far (Liang et al. 2010; Osterman et al. 2012). It is noteworthy that differences in the antigenicity of the ORF3 proteins of human gt1 and 4 HEV strains were observed (Ma et al. 2009). As with ORF3 proteins but to a lesser extent, the genotypespecific seroreactivity of ORF2 antigens was also found (Osterman et al. 2012). In this study, the ELISA recomWell HEV IgG which allows the detection of anti-HEV antibodies in human sera was adapted and optimized for detection of virus-specific antibodies in rabbit serum samples. The assay used utilizes O2C protein (432-660 aa) as antigen-capturing rabbit anti-HEV antibodies. This protein showed crossreactivity among different genotypes and subgenotypes of HEV strains isolated from humans, pigs, boars, and monkeys (Khudyakov et al. 1999; Li et al. 2000; Meng et al. 2001; Johne et al. 2014; Pérez-Gracia et al. 2014). As demonstrated in previous studies, the applicability of ORF2 recombinant proteins (ORF2 C-terminal portion; 394-660 aa and its truncated form at the $\mathrm{N}$ - and $\mathrm{C}$-terminals) in serodiagnostics of HEV infections in pigs has been shown (Pezzoni et al. 2014). Another diagnostically relevant region within ORF2 virus sequence encodes protein at position of 452-617 aa (Obriadina et al. 2002). Recently, the performance of several commercial assays for detection of anti-HEV antibodies in human and animal sera was evaluated (Zhang et al. 2011; Wenzel et al. 2013; Shrestha et al. 2016). The results indicated significant 
differences in the assays' diagnostic sensitivities. Additionally, assays based on proteins derived from ORF3 HEV may show poor sensitivities (Wang et al. 2001; Ma et al. 2009). In this study, a recombinant protein A reactive against the antigenic determinants of HEV strains was evaluated as a universal conjugate in ELISA. This native protein is able to bind with IgG antibodies present in sera of different mammals. It also permits use of the control sera supplied with the assay during its optimization. A panel of control rabbit sera was employed to gain better understanding about the correct test performance. They were selected according to the results obtained from molecular testing of pairs of samples, i.e., rabbit liver and serum collected from the same animal. Although a direct identification of the virus presence in rabbit sera was unsuccessful, the presence of HEV RNA in liver samples indicated animal seropositivity. Only one serum sample was positive for HEV RNA with a low level (63.97 U/ml) of anti-HEV antibodies determined by the use of the modified ELISA recomWell HEV IgG. Subsequent serological testing of other rabbit sera collected from HEVpositive animals also showed the presence of specific antiHEV antibodies. Consequently, OD values obtained for control sera and anti-human IgG conjugate gave most consistent performances when an appropriate concentration of protein A was used.

In summary, the use of serological tests for screening of animals at the farm level or those entering the food chain for the presence of potentially zoonotic viral pathogens is an efficient and inexpensive way to determine animal HEV seropositivity. As demonstrated here, the antibodies against rabbit HEV cross-reacted with $\mathrm{O} 2 \mathrm{C}$ capsid proteins derived from human gt3 HEV strains, confirming the suitability of the anti-HEV IgG (human) ELISA used for detection of antiHEV antibodies in rabbits. The results have also shown that protein A can be employed as the universal conjugate in ELISA, although a determination of its broad reactivity with sera of different animal species requires further studies.

Acknowledgements The authors would like to thank Dr. Iwona Kozyra for technical assistance during test optimization.

Funding This work was co-funded by research project No. S/198 and the KNOW (Leading National Research Centre) Scientific Consortium "Healthy Animal - Safe Food", under Ministry of Science and Higher Education decision No. 05-1/KNOW2/2015.

\section{Compliance with Ethical Standards}

Conflict of Interest Ewelina Bigoraj declares that she has no conflict of interest. Artur Rzeżutka declares that he has no conflict of interest.

Ethical Approval All applicable international, national, and/or institutional guidelines for the care and use of animals were followed.

Informed Consent Not applicable.
Open Access This article is distributed under the terms of the Creative Commons Attribution 4.0 International License (http:// creativecommons.org/licenses/by/4.0/), which permits unrestricted use, distribution, and reproduction in any medium, provided you give appropriate credit to the original author(s) and the source, provide a link to the Creative Commons license, and indicate if changes were made.

\section{References}

Abravanel F, Lhomme S, Dubois M, Peron JM, Alric L, Kamar N, Izopet J (2013) Hepatitis E virus. Med Mal Infect 43:263-270. https://doi. org/10.1016/j.medmal.2013.03.005

Anonymous (2014) European Commission Directorate-General for Agriculture and Rural Development. AGRI-2013-EVAL-03 Study Report Part B. Minor Meats

Burt SA, Veltman J, Hakze-van der Honing R, Schmitt H, van der Poel WH (2016) Hepatitis E virus in farmed rabbits, wild rabbits and petting farm rabbits in the Netherlands. Food Environ Virol 8: 227-229. https://doi.org/10.1007/s12560-016-9239-3

Caruso C, Modesto P, Prato R, Scaglione FE, De Marco L, Bollo E, Acutis PL, Masoero L, Peletto S (2015) Hepatitis E virus: first description in a pet house rabbit. A new transmission route for human? Transbound Emerg Dis 62:229-232. https://doi.org/10.1111/tbed. 12348

Cossaboom CM, Córdoba L, Sanford BJ, Piñeyro P, Kenney SP, Dryman BA, Wang Y, Meng XJ (2012) Cross-species infection of pigs with a novel rabbit, but not rat, strain of hepatitis $\mathrm{E}$ virus isolated in the United States. J Gen Virol 93:1687-1695. https://doi.org/10.1099/ vir.0.041509-0

Costanzo N, Sarno E, Peretti V, Ciambrone L, Casalinuovo F, Santoro A (2015) Serological and molecular investigation of swine hepatitis E virus in pigs raised in Southern Italy. J Food Prot 78:2099-2102. https://doi.org/10.4315/0362-028X.JFP-15-159

Dalle Zotte A, Szendro Z (2011) The role of rabbit meat as functional food. Meat Sci 88:319-331. https://doi.org/10.1016/j.meatsci.2011. 02.017

Di Bartolo I, De Sabato L, Marata A, Martinelli N, Magistrali CF, Monini M, Ponterio E, Ostanello F, Ruggeri FM (2016) Serological survey of hepatitis E virus infection in farmed and pet rabbits in Italy. Arch Virol 161:1343-1346. https://doi.org/10.1007/s00705-016-2778-y

Doceul V, Bagdassarian E, Demange A, Pavio N (2016) Zoonotic hepatitis E virus: classification, animal reservoirs and transmission routes. Viruses 3:8. https://doi.org/10.3390/v8100270

Dorning J, Harris S (2017) The welfare of farmed rabbits in commercial production systems. https://www.ciwf.org.uk/media/7430014/thewelfare-of-farmed-rabbits-in-commercial-production-systems-ascientific-review-february-2017.pdf

Eiden M, Schlosser M, Groschup J, Pourquier P, Comtet L (2011) Preliminary validation data of a commercial multi-species ELISA kit for detection of anti-hepatitis E virus antibodies in swine. Poster presented at the 6th International Symposium on Emerging and Reemerging Pig Diseases, Madrid, Spain

Emerson S, Purcell R (2003) Hepatitis E virus. Rev Med Virol 13:145154. https://doi.org/10.1002/rmv.384

FAO (2014) http://www.fao.org

Geng Y, Zhao C, Song A, Wang J, Zhang X, Harrison T, Zhou Y, Wang W, Wang Y (2011) The serological prevalence and genetic diversity of hepatitis E virus in farmed rabbits in China. Infect Genet Evol 11: 476-482. https://doi.org/10.1016/j.meegid.2010.12.012

Goumba CM, Yandoko-Nakouné ER, Komas NP (2010) A fatal case of acute hepatitis E among pregnant women, Central African Republic. BMC Res Notes 3:103. https://doi.org/10.1186/1756-0500-3-103 
Izopet J, Dubois M, Bertagnoli S, Lhomme S, Marchandeau S, Boucher S, Kamar N, Abravanel F, Guerin JL (2012) Hepatitis E virus strains in rabbits and evidence of a closely related strain in humans, France. Emerg Infect Dis 18:1274-1281. https://doi.org/10.3201/eid1808. 120057

Johne R, Dremsek P, Reetz J, Heckel G, Hess M, Ulrich RG (2014) Hepeviridae: an expanding family of vertebrate viruses. Infect Genet Evol 27:212-229. https://doi.org/10.3201/eid1808.120057

Jothikumar N, Cromeans TL, Robertson BH, Meng XJ, Hill VR (2006) A broadly reactive one-step real-time RT-PCR assay for rapid and sensitive detection of hepatitis E virus. J Virol Methods 131:6571. https://doi.org/10.1016/j.jviromet.2005.07.004

Khalafalla FA (1993) Microbiological status of rabbit carcases in Egypt. Z Lebensm Unters Forsch 196:233-235

Khudyakov Y, Kamili S (2011) Serological diagnostics of hepatitis E virus infection. Virus Res 161:84-92. https://doi.org/10.1016/j. virusres.2011.06.006

Khudyakov YE, Lopareva EN, Jue DL, Crews TK, Thyagarajan SP, Fields HA (1999) Antigenic domains of the open reading frame 2encoded protein of hepatitis E virus. J Clin Microbiol 37:2863-2871

Li F, Riddell MA, Seow HF, Takeda N, Miyamura T, Anderson DA (2000) Recombinant subunit ORF2.1 antigen and induction of antibody against immunodominant epitopes in the hepatitis E virus capsid protein. J Med Virol 60:379-386

Liang JH, Dai X, Dong C, Meng JH (2010) A single amino acid substitution changes antigenicity of ORF2-encoded proteins of hepatitis E virus. Int J Mol Sci 11:2962-2975. https://doi.org/10.3390/ ijms 11082962

Ma H, Song X, Li Z, Harrison TJ, Zhang H, Huang W, Hao W, Kong W, Wang Y (2009) Varying abilities of recombinant polypeptides from different regions of hepatitis E virus ORF2 and ORF3 to detect antiHEV immunoglobulin M. J Med Virol 81:1052-1061. https://doi. org/10.1002/jmv.21484

Maunula L, Kaupke A, Vasickova P, Söderberg K, Kozyra I, Lazic S, van der Poel WH, Bouwknegt M, Rutjes S, Willems KA, Moloney R, D'Agostino M, de Roda Husman AM, von Bonsdorff CH, Rzeżutka A, Pavlik I, Petrovic T, Cook N (2013) Tracing enteric viruses in the European berry fruit supply chain. Int J Food Microbiol 167:177185. https://doi.org/10.1016/j.ijfoodmicro.2013.09.003

Meng J, Dai X, Chang JC, Lopareva E, Pillot J, Fields HA, Khudyakov YE (2001) Identification and characterization of the neutralization epitope(s) of the hepatitis E virus. Virology 288:203-211. https:// doi.org/10.1006/viro.2001.1093

Nelson KE, Labrique AB, Kmush BL (2018) Epidemiology of genotype 1 and 2 hepatitis E virus infections. Cold Spring Harb Perspect Med a031732. https://doi.org/10.1101/cshperspect.a031732

Obriadina A, Meng JH, Ulanova T, Trinta K, Burkov A, Fields HA, Khudyakov YE (2002) A new enzyme immunoassay for the detection of antibody to hepatitis E virus. J Gastroenterol Hepatol 17: S360-S364

Osterman A, Vizoso Pinto MG, Haase R, Nitschko H, Jäger S, Sander M, Motz M, Mohn U, Baiker A (2012) Systematic screening for novel, serologically reactive hepatitis E virus epitopes. Virol J 9:28. https:// doi.org/10.1186/1743-422X-9-28
Pérez-Gracia MT, Suay B, Mateos-Lindemann ML (2014) Hepatitis E: an emerging disease. Infect Genet Evol 22:40-59. https://doi.org/10. 1016/j.meegid.2014.01.002

Pezzoni G, Caminiti A, Stercoli L, Grazioli S, Galletti G, Santi A, Tamba M, Brocchi E (2014) Comparison of three in-house ELISAs for the detection of hepatitis $\mathrm{E}$ virus infection in pigs under field conditions. J Virol Methods 207:95-103. https://doi.org/10.1016/j.jviromet. 2014.06.025

Pyz-Łukasik R, Szkucik K (2005) Bacterial contamination and sensory characteristics of rabbit tissues in relation to the place of slaughter and time of storage. Medycyna Wet 61:1162-1164

Riddell MA, Li F, Anderson DA (2000) Identification of immunodominant and conformational epitopes in the capsid protein of hepatitis E virus by using monoclonal antibodies. J Virol 74: 8011-8017

Shrestha AC, Flower RL, Seed CR, Stramer SL, Faddy HM (2016) A comparative study of assay performance of commercial hepatitis $\mathrm{E}$ virus enzyme-linked immunosorbent assay kits in Australian blood donor samples. J Blood Transfus 2016:9647675

Szkucik K, Pyz-Łukasik R (2009) Health quality of rabbit meat. Med Wet 65:665-669

Wang Y, Zhang H, Li Z, Gu W, Lan H, Hao W, Ling R, Li H, Harrison TJ (2001) Detection of sporadic cases of hepatitis E virus (HEV) infection in China using immunoassays based on recombinant open reading frame 2 and 3 polypeptides from HEV genotype 4. J Clin Microbiol 39:4370-4379

Wang H, Zhang W, Gu H, Chen W, Zeng M, Ji C, Song R, Zhang G (2017) Identification and characterization of two linear epitope motifs in hepatitis E virus ORF2 protein. PLoS One 28:e184947. https://doi.org/10.1371/journal.pone.0184947

Wenzel JJ, Preiss J, Schemmerer M, Huber B, Jilg W (2013) Test performance characteristics of anti-HEV IgG assays strongly influence hepatitis E seroprevalence estimates. J Infect Dis 207:497-500. https://doi.org/10.1093/infdis/jis688

Yugo DM, Meng XJ (2013) Hepatitis E virus: foodborne, waterborne and zoonotic transmission. Int J Environ Res Public Health 10:45074533. https://doi.org/10.3390/ijerph10104507

Zhang H, Mohn U, Prickett JR, Schalk S, Motz M, Halbur PG, Feagins AR, Meng XJ, Opriessnig T (2011) Differences in capabilities of different enzyme immunoassays to detect anti-hepatitis $\mathrm{E}$ virus immunoglobulin $\mathrm{G}$ in pigs infected experimentally with hepatitis $\mathrm{E}$ virus genotype 3 or 4 and in pigs with unknown exposure. J Virol Methods 175:156-162. https://doi.org/10.1016/j.jviromet.2011.05. 001

Zhao C, Wang Y (2016) Laboratory diagnosis of HEV infection. In: Wang Y (ed) Hepatitis E virus. Advances in Experimental Medicine and Biology, vol 948. Springer, Dordrecht. https://doi. org/10.1007/978-94-024-0942-0_11

Zhao K, Liu Q, Yu R, Li Z, Li J, Zhu H, Wu X, Tan F, Wang J, Tang X (2009) Screening of specific diagnostic peptides of swine hepatitis $E$ virus. Virol J 6:186. https://doi.org/10.1186/1743-422X-6-186

Zhou YH, Purcell RH, Emerson SU (2004) An ELISA for putative neutralizing antibodies to hepatitis $\mathrm{E}$ virus detects antibodies to genotypes 1, 2, 3, and 4. Vaccine 22:2578-2585. https://doi.org/10.1016/ j.vaccine.2003.12.017 